\title{
HOUSEHOLDS SAVINGS AND FINANCIAL BEHAVIOR IN RELATION TO THE ABILITY TO HANDLE FINANCIAL EMERGENCIES: CASE STUDY OF KOSOVO
}

\author{
Enkeleda Lulaj ${ }^{\natural 凶}$, Blerta Dragusha², Donjeta Lulaj', Vjollca Rustaj', \\ Albiona Gashi ${ }^{1}$ \\ 'University of Peja "Haxhi Zeka", Kosovo \\ ${ }^{2}$ University of Shkodra "Luigj Gurakuqi", Albania
}

\begin{abstract}
To reflect the financial situation of households, especially for emergencies, the main purpose of this research is to analyze financial behavior in relation to savings. This research explains the interaction of minimum savings rules and committed forms of saving, which means that the use of personal budgets depends on financial behavior due to insecurity and the financial situation of families. The research is consistent with some empirical findings on financial behavior in relation to savings, which affect the growth or decline of the economy, because the lower the well-being of families the lower the economic growth or vice versa. The validation of the hypotheses was realized through the analysis of field findings, using the econometric model of savings in relation to financial behavior through factor analysis, reliability analysis and multiple regression analysis. The main finding of this research is the lack of financial behavior to save for emergencies. These findings are important in order for households to be aware of financial behavior in relation to savings, because there is no emergency fund to cover their needs.
\end{abstract}

Key words: Savings, financial behavior, multiple regression analysis, households, growth and decline economics.

JEL codes: C1, R12, M4

\section{INTRODUCTION}

There are many people who have lost money or not saved properly. Some economic models argue that households need to effectively save money to cope with emergencies [Gokhale and Kotlikoff 1999]. The key is to identify spending behaviors. A family can become immersed in debt by buying luxury items (car, house, expensive brand-name clothing, etc.), not saving for emergencies in order to look beautiful or successful in the eyes of others rather than practicing good financial behavior. Moreover, families often borrow from rela- tives and friends. For example, during the Great Recession about $24 \%$ of American households borrowed money from a family member or friend. [Morin et al. 2010].

Financial advisors can help households a lot in terms of savings and financial behavior [Baker et al. 2017]. Households that save for emergencies have higher incomes and are financially educated or have better financial behavior than households that are not financially educated [Lawson and Hershey 2005, Lusardi and Mitchelli 2007, Rooij et al. 2011]. It is very important for households to know that financial be- 
Lulaj, E., Dragusha, B., Lulaj, D., Rustaj, V., Gashi, A. (2021). Households savings and financial behavior in relation to the ability to handle financial emergencies: case study of Kosovo. Acta Sci. Pol. Oeconomia 20 (1), 35-47, DOI: 10.22630/ASPE.2021.20.1.4

havior that includes savings helps to get out of emergency situations [Mandell and Klein 2009].

Researchers analyzed financial behavior through an international consumer finance questionnaire, forming a financial practice based on four variables of financial behavior: cash flow management, credit management, savings and investment practices. According to this result, they emphasized that households with good financial behavior have increased savings [Hilgert et al. 2003]. If high school students learn about budgeting and using credit or debt, the knowledge and skills acquired during that time are more likely to continue during university and in their jobs [Castellani and DeVaney 2001]. Other studies also show the need for better personal financial behavior in relation to savings [Hilgert et al. 2003]. Some of the previous practices emphasize that households have been uninformed about financial behavior in relation to savings. [Stephen 1988, Gustman and Steinmeier 2000]. Other findings on financial behavior in relation to savings also show that some low-income households save more in various forms than higher-income and more educated families. Therefore, programs should be designed to adapt to the needs and barriers related to saving. [Schreiner and Sherraden 2007].

\section{LITERATURE REVIEW}

The economic literature usually analyzes the relationships between economic growth and savings using correlation coefficient and dynamic econometric models [Bacha 1990]. In order to analyze the relationship between savings and economic growth through financial behavior, econometric methods have been used. The research proved that the higher the level of domestic savings, the higher the economic growth rate of households and the country in general [Misztal 2011]. From the point of view of a standard theory of economics, a positive correlation between savings, financial behavior and economic growth can emerge in advanced economies, while in poor countries there is less of a relationship between these variables than is found in developed countries.

According Shin and Kim [2018], savings are an important means by which American households accumulate wealth to meet their financial goals, such as pre- paring for retirement, saving for college, educating and protecting their assets against unpredictable stochastic risks, etc. Many studies argue that personal savings depend on the financial behavior of the individual [Aguiar and Amador 2011], which includes expenditures and revenues divided into categories in certain time periods (weeks, months, years, etc.) [Nageeb 2011] and which should be adjusted according to the circumstances of the household [Jamieson and Jamieson 2009]. Research by F. Gómez [2009] emphasizes the importance of financial behavior as a condition for increasing household savings. But there are no absolute results on saving according to Bajtelsmit, Bernasek and Jianakoplos [1999], given the other factors (education level, income, country economy, employment, financial situation, etc.) which affect the financial behavior of savings.

According Karlan and Morduch [2009] in research analyzing the differences between lower and higher income people, they pointed out that lower income people do not have savings accounts, unlike the higher income group. Other researchers [King and Levine 1993, Beck et al. 2000, Klapper et al. 2006, Beck et al. 2007] in analyzed savings from the perspective of financial behavior in the investments people make. All proved that the state should provide financial stability and economic growth for the needs of the people by promoting innovation or development culture to enable people to save, because by investing their savings, they can generate profits and thus increase their legacy and awareness of financial behavior in relation to savings [Lulaj 2020]. Similar analysis has been given by other analysts [Scholtz 1992, Bernheim and Garrett 1996, Bajtelsmit et al 1999].

Studies have shown that demographic factors also have a major impact on saving money, resulting in recommendations that most working households should save money, due to new reforms that may come in the future [Kotlikoff and Morris 1989, Wiatrowski 1993, Sterns, 1998, Ferraro 1999, Kleinman et al. 1999]. Additional research concluded that the economic growth of households is influenced by the financial behavior of individuals in managing their budget in relation to savings [Sonuga and Webley 1993, Furnham 1999, Karlan and Morduch 2009].

There are many studies that emphasize that focusing financial behavior as part of financial management 
Lulaj, E., Dragusha, B., Lulaj, D., Rustaj, V., Gashi, A. (2021). Households savings and financial behavior in relation to the ability to handle financial emergencies: case study of Kosovo. Acta Sci. Pol. Oeconomia 20 (1), 35-47, DOI: 10.22630/ASPE.2021.20.1.4

has positive effects on financial stability and well-being by increasing the level of savings. Some analysis has shown that low-income households, which reported any reason for saving (savings motives) were more likely to be better savers compared to those without savings motives [Meier and Sprenger, 2008; Sherraden 1991, Hogarth and Anguelov 2003, Schreiner and Sherraden 2007, Fry et al. 2008]. Households are responsible for significant savings in all countries [Hebbel et al. 1992].

In various literature it is pointed out that the level of savings in relation to financial behavior in households can be influenced by many different factors such as: external factors (macro) and internal factors (micro). Some of the macroeconomic factors that affect household savings are (overall GDP ratio), income level, growth rates of households with disposable income, unemployment rate, real interest rate, inflation rate, etc. [Callen and Thiman 1997]. While microeconomic factors that affect the financial situation of households are savings in relation to financial behavior [Fehr and Hishigsuren 2006]. In general, savings can be defined as money that is not spent at the moment, because people usually save so they can buy more later. Without savings, households find it more difficult to have a secure financial situation in extraordinary situations [Chowdhury 2004].

Economic, social, demographic and cultural factors determine the behavior of households to save [Niculescu and Mihaescu 2014]. Household savings indicate the level of living conditions or financial situation [Zhuk 2015]. Households cannot make changes in savings until they identify where they spend their money or have good financial behavior. Relationships of families with money are quite complicated; people often buy for many reasons other than necessity [Dupas and Robinson 2013]. There are also many characteristics of financial behavior in relation to savings, often unobservable for households and the environment, determining how much wealth people want to keep, including the degree of risk in emergencies, time preferences and the subjective probability of coping with shocks [Deaton 1992]. Households may fail to save for emergencies because they lack financial behavior, failing to adequately assess the risk of a money emergency [Collins and Gjertson 2013]. In theory, households need to save for emergencies in order to protect themselves from unexpected risks [Deaton 1992]. Analyzes made by many studies have found a strong link between financial behavior and savings, but recent findings show that subjective behavior may be a more effective predictor of financial behavior than objective knowledge about savings [Robb and Woodyard 2011].

Based on the numerous studies in the literature review, the findings will help with this case study of households regarding their behavior in relation to savings.

\section{DATA AND METHODOLOGY}

The research includes households throughout the country of Kosovo during the years 2019-2020. The interview was conducted through a questionnaire for all households; in this case 5000 people were interviewed. The findings are elaborated in Tables, giving recommendations for the future. The issues that were considered when choosing the procedure to evaluate savings in relation to financial behavior are: first, allowing a savings ratio that results from the residual effects of explanatory variables on savings [Chowdhury 2015]; second, some regressors included in the equation such as savings factors and financial behavior may be jointly significant, i.e. related to the term error; third, specific factors of savings and unobserved financial behavior may be correlated with explanatory variables that produce biased and inconsistent estimates.

To address these issues, the research is based on a data analysis technique through the method of factor analysis, reliability analysis and multiple linear regression analysis. The factor analysis model presents statistical techniques in more variables, or variables whose purpose is to reduce the number of variables that are related to each other to a smaller number, independent of each other, named as a factor. Therefore, this analysis simultaneously tests the integrity of the measurement and guides the further improvement of the theory. In this case this analysis deals with the variables of savings and financial behavior [Henson and Roberts 2006].

According to Kieffer, the use of factor analysis techniques in the social sciences is inextricably intertwined with both development theories and the assessment of the construct validity of austerity factors and financial behavior [Kieffer 1999]. When saving factors and financial behavior during analysis are fac- 
tored [Campbell 1996], then the total number of factors is equal to the number of variables [Thompson and Larry 1996].

The model of factor analysis for savings, in algebraic form is marked in this way: If $p$ variables $x_{1}, x_{2}$, $x_{3}, \ldots ., x_{p}$, are measured in a sample of $n$ subjects, then the variable $i$ can be denoted as a linear combination of $m$ factors $F_{1}, F_{2}, F_{3}, F_{k}, k<p$, [Bai at al. 2015].

$$
x_{i}=\alpha_{i^{1}} F_{1}+\alpha_{i^{2}} F_{2}+\alpha_{i^{k}} F_{k}+\ldots+\mu_{i}
$$

Where: $\alpha_{i}$, are factor loads or results for savings and financial behavior variables, and $\mu_{i}$ is the part of variable $x_{i}$ that cannot be explained by the factors or error term. The principal component model is transformed into the Factor model for savings and financial behavior as in the following equation.

$$
\begin{aligned}
X_{i}= & \sum_{j=1}^{m} a_{i j} P C_{j}, \quad i=1,2, \ldots, k, \quad j=1,2, \ldots, m \\
& \sum_{j=1}^{m} a_{i j} F_{i} \sqrt{\lambda_{i}}, \quad L_{i j}=a_{i j} \sqrt{\lambda_{i}} \\
& \sum_{j=1}^{m} L_{i j} F_{i}
\end{aligned}
$$

Referring to earlier analysis by Richardsonand Kuder [Feld 1969], Cronbach claims that by making the same assumptions, but removing the limitations in the model, we have the mathematical equation which we denote by the sign alpha $(\alpha)$ [Cronbach and Goldine 1959]:

$$
\alpha=\frac{p}{1-p}\left(1-\sum_{i=1}^{p} \sigma x_{i}^{2} / \sigma_{\mu}^{2}\right)
$$

where:

$p \quad$ - the number of variables (items),

$\sigma x i_{2}$ - the variance of the values of $i$,

$\sigma x \mu_{2}-$ the total variance of results for the savings and financial behavior,

$\mu=x_{1}+x_{2}+\ldots+x_{p}$

To test the significance of the data for each factor of savings and financial behavior, we used the $t$ test, while to test whether the model as a whole is impor- tant, we used the $F$ test [Zsuzsannaa and Liviu 2012]. The following equation presents the multiple linear regression model to the savings and financial behavior of households [Bremer 2012]:

$$
Y=\beta_{0}+\beta_{1} x_{1}+\beta_{2} x_{2}, \ldots . .+\beta_{k} x_{k}+\mu
$$

Where:

$Y$ - dependent variable,

$x_{1}, x_{2}, x_{3}, \ldots, x_{n}$ - independent variables $\beta_{0}, \beta_{1}, \beta_{2}, \ldots$,

$\beta_{k}$ - linear parameters (estimated),

$\mu$ - error term,

$k$ - number of terms in the model: $x_{3}=x_{1}^{2}, x_{4}=x_{2}^{3}$, $x_{5}=x_{1} x_{2}($ replaced by $k$ ).

The model of interaction between variables $x_{1} x_{2}$ is as follows:

$$
Y=\beta_{0}+\beta_{1} x_{1}+\beta_{2} x_{2}, \ldots \beta_{12} x_{1} x_{2},+\mu
$$

The multiple linear regression model squaring force in savings and financial behavior is used to find the optimal response values from the RMS analysis (surface optimal response methods) for all variables.

$$
Y=\beta_{0}+\beta_{1} x_{1}+\beta_{2} x_{1}^{2}+\beta_{3} x_{1}^{3}+\mu
$$

We consider the multiple linear regression model with predictive variables for savings and financial behavior:

$$
Y=\beta_{0}+\beta_{1} x_{1}+\beta_{2} x_{2}, \ldots,+\beta_{k} x_{k},+\mu
$$

Using $\mathrm{k}$ for each of the predictive variables of savings and financial behavior for $x_{1}, x_{2}, x_{3}$, for each level $(n)$. Then $X_{i j}$ represents the level $i$ and $j$ for the predicted variables of $X_{j}$. Observations $Y_{1}, Y_{2}, \ldots ., Y_{n}$, for each $n$ level are presented through this equation to savings and financial behavior in emergencies cases.

$$
\begin{aligned}
& Y_{1}=\beta_{0}+\beta_{1} x_{11}+\beta_{2} x_{12}, \ldots,+\beta_{k} x 1_{k}+\mu_{1} \\
& Y_{2}=\beta_{0}+\beta_{1} x_{21}+\beta_{2} x_{22}, \ldots,+\beta_{k} x_{2 k}+\mu_{2} \\
& Y_{i}=\beta_{0}+\beta_{1} x_{i 1}+\beta_{2} x_{i 2}, \ldots,+\beta_{k} x_{i k}+\mu_{i} \\
& Y_{n}=\beta_{0}+\beta_{1} x_{n 1}+\beta_{2} x_{n 2}, \ldots,+\beta_{k} x_{n k}+\mu_{n}
\end{aligned}
$$


Lulaj, E., Dragusha, B., Lulaj, D., Rustaj, V., Gashi, A. (2021). Households savings and financial behavior in relation to the ability to handle financial emergencies: case study of Kosovo. Acta Sci. Pol. Oeconomia 20 (1), 35-47, DOI: 10.22630/ASPE.2021.20.1.4

The system of equations $n$ presented above is represented by the matrix symbol as in the following equation shows the savings and financial behavior [Tampis and Urrutia 2017].

\section{THE MAIN HYPOTHESES}

Another purpose of this research is to take a closer look at the financial situation of households in relation to savings, given the coronavirus pandemic that has swept the world. The question of how well households are able to cover emergencies through previous savings has become now become even more relevant.

Financial behavior of households in relation to savings $=\beta_{0}+\beta_{1}$ (Financial behavior related to saving) $+\beta_{2}$ (Savings funds based on financial behavior) $+\beta_{3}$ (Implications or non-saving due to financial behavior) $+\mu$
$\mathrm{H}_{0}$ : Savings factors and financial behavior are not important (do not have a positive effect) on households for emergencies.

$\mathrm{H}_{\wedge}$ : Savings factors and financial behavior are important (have a positive effect) on households for emergencies, or

$$
\mathrm{H}_{0}=\boldsymbol{\beta}_{1}=\boldsymbol{\beta}_{2}=\boldsymbol{\beta}_{3}=\beta_{4}=\beta_{5}=\beta_{6}=\beta_{7}=\beta_{8}=0
$$

$\mathrm{H}_{\mathrm{A}}=\boldsymbol{\beta}_{1} \neq 0-$ not all parameters are equal to zero

\section{ANALYSIS OF THE RESULTS}

Findings have emerged as a result of several types of analyzes of the survey data: Factorial analysis, reliability analysis, multiple linear regression analysis, including all tests within these analyzes.

Table 1 shows the following findings: in the employment variable, the largest number of responses

Table 1. Frequency analysis of respondents to questionnaire

\begin{tabular}{|c|c|c|c|}
\hline Variables & & Frequency & $(\%)$ \\
\hline \multirow{2}{*}{ Gender } & M & 47 & 37.6 \\
\hline & $\mathrm{F}$ & 76 & 60.8 \\
\hline \multirow{5}{*}{ Age } & $18-24$ & 29 & 23.2 \\
\hline & $25-34$ & 50 & 40.0 \\
\hline & $35-44$ & 35 & 28.0 \\
\hline & $45-59$ & 9 & 7.2 \\
\hline & over 60 & 1 & 8 \\
\hline \multirow{5}{*}{ Employment } & full time & 52 & 41.6 \\
\hline & part time & 16 & 12.8 \\
\hline & rarely work & 2 & 1.6 \\
\hline & there are employed by my family & 6 & 4.8 \\
\hline & I'm unemployed & 21 & 16.8 \\
\hline \multirow{4}{*}{ Members of the family } & 1-3 member & 13 & 10.4 \\
\hline & 3-5 member & 56 & 44.8 \\
\hline & 5-7 member & 45 & 36.0 \\
\hline & Over 7 members & 10 & 8.0 \\
\hline \multirow{5}{*}{ Income } & EUR 100-300 & 25 & 20 \\
\hline & EUR $300-500$ & 31 & 24.8 \\
\hline & EUR 500-1000 & 26 & 20.8 \\
\hline & over EUR 1000 & 23 & 18.4 \\
\hline & there is no answer & 9 & 7.2 \\
\hline
\end{tabular}

Source: Authors' own computations based on the survey data. 
Lulaj, E., Dragusha, B., Lulaj, D., Rustaj, V., Gashi, A. (2021). Households savings and financial behavior in relation to the ability to handle financial emergencies: case study of Kosovo. Acta Sci. Pol. Oeconomia 20 (1), 35-47, DOI: 10.22630/ASPE.2021.20.1.4

were given by full-time employees at a percentage of $41.6 \%$. In the gender variable, women gave the greatest number of responses, $60.8 \%$. In the age variable, the largest number of responses were from persons in the age group $25-34$ years, at $40 \%$. In the family variable, the largest response group had families of 3-5 members, at $44.8 \%$. In the income variable, families with monthly income of EUR 300-500 had the highest number of respondents, at $24.8 \%$.

Table 2 explains the KMO (.884 >0.50, Sig .000), variance $(66.58 \%>.50$.), and Alpha $(.892 \leq \alpha \leq 1.00)$. The data on savings and financial behavior of households for emergencies are suitable for the model and have very high reliability for factor analysis.
Table 3 explains that the data are suitable for analysis, because the variances have a value greater than .500 . The variables with the highest variance are .757 and .754 (variables 6 and 7). Through the rotation phase, the factor of savings and financial behavior in households in exceptional cases is divided into three sub-factors by naming them: Financial behavior related to saving (FBRS), Savings funds based on financial behavior (SFBFB), Implications or non-saving due to financial behavior (IFB).

\section{Factor I - Financial behavior related to saving}

Exits from the econometric model for factor I: KMO $=.877, \mathrm{SIG}=000 \mathrm{TVE}=66.23 \%, \mathrm{RCM}=1(6)$,

Table 2. KMO, variance and Cronbach Alpha results from questionnaire

\begin{tabular}{lccccc}
\hline KMO and Barlett test & & Factors & Eigen value & \% of variance & Cronbach 's Alpha \\
\hline KMO & $\mathbf{. 8 8 4}$ & 1 & 5.677 & 31.188 & \\
Barlett test & 685.426 & 2 & 1.283 & 49.101 & $\mathbf{8 9 2}$ \\
$D F$ & 66 & 3 & 1.030 & $\mathbf{6 6 . 5 8 1}$ & \\
Sig. & .000 & 12 & .207 & & \\
\hline
\end{tabular}

Source: Authors' own computations based on survey data.

Table 3. Common variances and factor matrix of questionnaire

\begin{tabular}{|c|c|c|c|c|c|}
\hline \multirow[t]{2}{*}{ Item } & \multicolumn{2}{|c|}{ Principal component analysis } & \multicolumn{3}{|c|}{ Factor matrix (RCM) } \\
\hline & Start & Extraction & FBRS & SFBFB & IFB \\
\hline 1 & 1.000 & .585 & .831 & .115 & .167 \\
\hline 2 & 1.000 & .642 & .828 & .183 & .194 \\
\hline 3 & 1.000 & .657 & .819 & .014 & .286 \\
\hline 4 & 1.000 & .528 & .741 & .249 & .315 \\
\hline 5 & 1.000 & .711 & .688 & .404 & .143 \\
\hline 6 & 1.000 & .732 & .585 & .582 & .342 \\
\hline 7 & 1.000 & .757 & .055 & .830 & .006 \\
\hline 8 & 1.000 & .754 & .409 & .652 & .076 \\
\hline 9 & 1.000 & .611 & .134 & .608 & .404 \\
\hline 10 & 1.000 & .724 & .165 & .327 & .768 \\
\hline 11 & 1.000 & .598 & .214 & -.118 & .684 \\
\hline 12 & 1.000 & .692 & .417 & .201 & .629 \\
\hline
\end{tabular}

Source: Authors' own computations based on survey data. 
Lulaj, E., Dragusha, B., Lulaj, D., Rustaj, V., Gashi, A. (2021). Households savings and financial behavior in relation to the ability to handle financial emergencies: case study of Kosovo. Acta Sci. Pol. Oeconomia 20 (1), 35-47, DOI: 10.22630/ASPE.2021.20.1.4

ALPHA $=.895$, ITEM $=6$. KMO $(.877>0.50$, Sig $.000)$, variance $(66.23 \%>.50$.), and Alpha $(.895 \leq \alpha \leq$ 1.00.). Financial behavior data in relation to savings, are suitable for the model and have very high reliability for factor analysis. The variance with the highest variance is .852 (variable 2 ).

\section{Factor II - Savings funds based on financial behavior}

Exits from the econometric model for factor II: KMO $=.759, \mathrm{SIG}=000 \mathrm{TVE}=55.94 \%, \mathrm{RCM}=1(4), \mathrm{AL}-$ PHA $=.895$, ITEM $=6$. KMO $(.729>0.50$, Sig .000), variance $(55.94 \%>.50$. $)$, and Alpha $(.729 \leq \alpha \leq 1.00$. $)$. Savings fund data based on financial behavior, are suitable for the model and have very high reliability for factor analysis. The variable with the highest variance is .754 (variable 1).

\section{Factor III - Implications or non-saving due to financial behavior}

Exits from the econometric model for factor III: KMO $=.775, \mathrm{SIG}=000 \mathrm{TVE}=59.93 \%, \mathrm{RCM}=1(3)$, ALPHA $=.895$, ITEM $=6$. KMO $(.863>0.50$, Sig.000), variance $(59.93 \%>.50$.), and Alpha $(.863 \leq$ $\alpha \leq 1.00$.). Data of implications or non-savings due to financial behavior, are suitable for the model and have very high reliability for factor analysis. The variance with the highest variance is .884 or (variable 1 ).

Table 4 shows that $91 \%(R=.915$, Sig. $=000$, $F=41.1764$ ) for Factor I or FBRS, depends on the independent variables (saving and investment are important $-\mathrm{RKI}$, saving as cash $-\mathrm{KPG}$, savings such as deposits or non-withdrawal of money from accounts - KD, savings for consumption - KK, savings for health and home - KSHK, savings for necessities and survival of the family - KNM), while $9 \%$ depends on other variables outside this model by random error. Adjusted $R^{2}$ in the value of .927 indicates that $93 \%$ of the variables are related to the model, while according to the Durbin-Watson test (1.168) the model is significant and the auto correlation is negative, which means that the $S D$ of coefficient b or financial behavior in relation to savings is very small.

Table 5 shows the parameter values of the predicted model results and the $t$ values by analyzing them for each variable at the $5 \%$ significance level. The constant in the value of .185 shows that if the financial behavior in relation to savings is based on: independent variables (RKI, KPG, KD, KK, KSHSH, KNM) is zero, then this variable is correct $22 \%$. If the financial behavior in relation to savings is done in accordance with the independent variables, the accuracy will be $144 \%(\mathrm{RKI}=17 \%, \mathrm{KPG}=5 \%, \mathrm{KD}=37 \%, \mathrm{KK}=$ $49 \%$, KSHSH $=19 \%, \mathrm{KNM}=17 \%)$. The Beta coefficient shows that all the independent variables are important in the model, but the variable which is most important is the consumption saving at $49 \%$. Collinearity statistics including tolerance and VIF values $(1.300=$ $.892, .884=.867,2.775=1.892,1.432=1.521)$ are important in the model because there is no problem of multiple relationships between independent variables.

$$
\begin{aligned}
\hat{y}= & \alpha_{0}+\beta_{1}(\mathrm{RKI})+\beta_{2}(\mathrm{KPG})+\beta_{3}(\mathrm{KD})+\beta_{4}(\mathrm{KK})+ \\
& +\beta_{5}(\mathrm{KSHSH})+\beta_{6}(\mathrm{KNM}) \\
= & 0.218+0.172 x_{1}+0.054 x_{2}+0.371 x_{3}+0.495 x_{4}+ \\
+ & 0.191 x_{5}+0.172 x_{6}+0.07 \mu
\end{aligned}
$$

\begin{tabular}{|c|c|c|c|c|c|c|c|c|c|c|}
\hline \multicolumn{11}{|c|}{ Model Summary } \\
\hline \multirow{2}{*}{ Model } & \multirow{2}{*}{$R$} & \multirow{2}{*}{$R^{2}$} & \multirow{2}{*}{$\begin{array}{l}\text { Adjusted } \\
R\end{array}$} & \multirow{2}{*}{$\begin{array}{l}S D \text { of the } \\
\text { estimate }\end{array}$} & \multicolumn{6}{|c|}{ Change statistics - Anova } \\
\hline & & & & & $R^{2}$ & $F$ & Df. 1 & Df. 2 & Sig. & Durbin-Watson \\
\hline 1 & .915 & .813 & .927 & .18221 & .813 & 41.1764 & 2 & 35 & .000 & 1.168 \\
\hline
\end{tabular}

$$
\begin{aligned}
F & =\frac{R^{2} / k}{\left(1-R^{2}\right) /(n-k-1)}=\frac{.813 / 2}{(1-.813) / 35}= \\
& =\frac{0.4065}{0.187 / 35}=\frac{0.22}{0.00534286}=41.1764
\end{aligned}
$$

Table 4. Summary of the model for financial behavior related to saving

Source: authors' own computations 
Lulaj, E., Dragusha, B., Lulaj, D., Rustaj, V., Gashi, A. (2021). Households savings and financial behavior in relation to the ability to handle financial emergencies: case study of Kosovo. Acta Sci. Pol. Oeconomia 20 (1), 35-47, DOI: 10.22630/ASPE.2021.20.1.4

Table 5. Coefficients for financial behavior in relation to savings

\begin{tabular}{|c|c|c|c|c|c|c|c|c|}
\hline \multicolumn{9}{|l|}{ Coefficients } \\
\hline & & \multicolumn{7}{|l|}{ Model } \\
\hline & & constant & RKI & KPG & $\mathrm{KD}$ & KK & KSHSH & KNM \\
\hline \multirow[t]{2}{*}{ Unstandardized coefficients } & $B$ & .218 & .172 & .054 & .371 & .495 & .191 & .172 \\
\hline & $S D$ & .275 & .114 & .074 & .075 & .122 & .275 & .114 \\
\hline Standardized coefficients & beta & & .211 & .082 & .409 & .499 & & .211 \\
\hline$t$ & & .675 & 1.708 & .1 .002 & 5.134 & 3.910 & .675 & 1.708 \\
\hline Sig. & & .000 & .007 & .003 & .000 & .000 & .000 & .007 \\
\hline \multirow[t]{2}{*}{$95.0 \%$ Confidence interval for $B$} & lower bound & -.373 & -.037 & -.125 & .232 & .228 & -.373 & -.037 \\
\hline & upper bound & .744 & .425 & .076 & .538 & .722 & .744 & .425 \\
\hline \multirow[t]{2}{*}{ Collinearity statistics } & tolerance & & 1.300 & .892 & .963 & .867 & & 1.400 \\
\hline & VIF & & 2.775 & 1.892 & 1.432 & 1.521 & & 2.173 \\
\hline
\end{tabular}

Dependent variable: Financial behavior in relation to savings

Source: Authors' own computations.

Reliability interval is $95 \%$ (Sig. 2-tailed), $p=0.000$ $<0.05, t=1.708, .1 .002,5.134,3.910>.573)$, the value of $\mathrm{p}$ is less than the significance level $5 \%$, so $\mathrm{H}_{0}$ is rejected and accepted $\left(\beta_{1}, \beta_{2}, \beta_{3}, \beta_{4}, \beta_{5}, \beta_{6}\right) \neq 0$.

Table 6 shows that $91 \%(R=.912$, Sig. $=000, F=$ 51.824) for Factor II depends on the independent variables (Survival savings - CMC, Unspent money savings - KPPSH, Savings related to the financial situation - KLSF, Emergency Savings Funds - FKU), while $9 \%$ depends on other variables outside this model by random error. Adjusted $R^{2}$ at a value of .892 indicates that $89 \%$ of the variables are related to the model, while according to the Durbin-Watson test (1.136) the model is significant and the auto correlation is negative, which means that the $S D$ of the coefficient $b$ or Factor II is very small.
Table 7 shows the parameter values of the predicted model results and the $t$ values by analyzing them for each variable at the $5 \%$ significance level. The constant value of $34 \%$ shows that if the savings funds based on independent variables: KMK, KPPSH, KLSF, FKU is zero, then the savings funds based on financial behavior have an accuracy of $34 \%$. If the saved funds are made in accordance with the independent variables, the accuracy will be $74 \%(\mathrm{KMK}=17 \%, \mathrm{KPPSH}=57 \%$, $\mathrm{KLSF}=9 \%, \mathrm{FKU}=-9 \%$,). Beta coefficient shows that all independent variables are important in the model, the most important variable is $\mathrm{KPPSH}=62 \%$. Collinearity statistics including tolerance and VIF values $(.590=.842, .331=.739, .288=.453, .283=.735)$ are important in the model because there is no problem of multiple relationships between independent variables.

Table 6. Summary of the model for savings funds based on financial behavior

\begin{tabular}{|c|c|c|c|c|c|c|c|c|c|c|}
\hline \multicolumn{11}{|c|}{ Model Summary } \\
\hline \multirow{2}{*}{ Model } & \multirow{2}{*}{$R$} & \multirow{2}{*}{$R^{2}$} & \multirow{2}{*}{$\begin{array}{l}\text { Adjusted } \\
R\end{array}$} & \multirow{2}{*}{$\begin{array}{l}S D \text { of the } \\
\text { estimate }\end{array}$} & \multicolumn{6}{|c|}{ Change Statistics - Anova } \\
\hline & & & & & $R^{2}$ & $F$ & Df. 1 & Df. 2 & Sig. & Durbin-Watson \\
\hline 1 & .962 & .912 & .892 & .16461 & .912 & $\mathbf{5 1 . 8 2 4 0 7}$ & 6 & 30 & .000 & 1.136 \\
\hline
\end{tabular}

Source: Authors' own computations. 
Lulaj, E., Dragusha, B., Lulaj, D., Rustaj, V., Gashi, A. (2021). Households savings and financial behavior in relation to the ability to handle financial emergencies: case study of Kosovo. Acta Sci. Pol. Oeconomia 20 (1), 35-47, DOI: 10.22630/ASPE.2021.20.1.4

Table 7. Coefficient for savings funds based on financial behavior

\begin{tabular}{lllllll}
\hline Coefficients & \multicolumn{1}{l}{ Model } & & & & \\
& & & & & \\
& & constant & KMK & KPPSH & KLSF & FKU \\
\hline Unstandardized coefficients & $B$ &. $\mathbf{3 4 1}$ & $\mathbf{. 1 7 6}$ & $\mathbf{. 5 7 1}$ & $\mathbf{. 0 8 7}$ & -.916 \\
\hline & $S D$ & .170 & .130 & .087 & .221 & .188 \\
\hline Standardized coefficients & Beta & & .130 & .617 & .736 & -.721 \\
\hline $\mathrm{t}$ & & -.525 & .854 & 5.767 & 3.403 & -5.87 \\
\hline Sig. & & $\mathbf{. 0 0 0}$ & $\mathbf{. 0 0 0}$ & $\mathbf{. 0 0 0}$ & $\mathbf{. 0 0 0}$ & $\mathbf{. 0 0 0}$ \\
\hline $95.0 \%$ confidence interval for $B$ & lower bound & -.437 & -.142 & .426 & .499 & -1.14 \\
\hline & upper bound & .258 & .390 & .780 & 1.402 & -.344 \\
\hline Collinearity statistics & tolerance & & $\mathbf{. 5 9 0}$ & $\mathbf{. 3 3 1}$ & $\mathbf{. 2 8 8}$ & $\mathbf{. 2 8 3}$ \\
\hline & VIF & & .842 & .739 & $\mathbf{. 4 5 3}$ & $\mathbf{. 7 3 5}$ \\
\hline
\end{tabular}

Dependent variable: savings funds based on financial behavior

Source: authors' own computations

$$
\begin{aligned}
\hat{y}= & \alpha_{0}+\beta_{1}(\mathrm{KMK})+\beta_{2}(\mathrm{KPPSH})+\beta_{3}(\mathrm{KLSF})+ \\
& +\beta_{4}(\mathrm{FKU}) \\
& =0.341+0.176 x_{1}+0.571 x_{2}+0.087 x_{3}- \\
& -0.916 x_{4}+0.011 \mu \\
F= & \frac{R^{2} / k}{\left(1-R^{2}\right) /(n-k-1)}=\frac{.912 / 6}{(1-.912) / 30}=\frac{0.152}{0.088 / 30}= \\
= & \frac{0.152}{0.002933}=51.82407
\end{aligned}
$$

Reliability interval 95\% (Sig. 2-tailed), $p=0.000$ $<0.05, t=.854,5.767,3.403,-5.87>.223$, the value of $p$ is less than the significance level $5 \%, \mathrm{H}_{0}$ is rejected and accepted $\left(\beta_{1}, \beta_{2}, \beta_{3}\right) \neq 0, \beta_{4}=0$, i.e. there are not enough funds for emergencies .
Table 8 shows that $96 \%(R=.959$, Sig. $=000, F$ $=304.074)$ for Factor III depends on the independent variables (Investments in luxury items - INVLL, Lack of awareness about saving and increasing concerns about extraordinary situations - MVKRRSH, excessive giving of money to family or friends - HTFM), while $4 \%$ depends on other variables outside this model by random error. Adjusted $R^{2}$ in the value of .867 indicates that $87 \%$ of the variables are related to the model, while according to the Durbin-Watson test (1.841) the model is significant and the auto correlation is negative, which means that the $S D$ of the coef-

\begin{tabular}{|c|c|c|c|c|c|c|c|c|c|c|}
\hline \multicolumn{11}{|c|}{ Model Summary } \\
\hline \multirow{2}{*}{ Model } & \multirow{2}{*}{$R$} & \multirow{2}{*}{$R^{2}$} & \multirow{2}{*}{$\begin{array}{l}\text { Adjusted } \\
R\end{array}$} & \multirow{2}{*}{$S D$} & \multicolumn{6}{|c|}{ Change Statistics - Anova } \\
\hline & & & & & $R^{2}$ & $F$ & Df. 1 & Df. 2 & Sig. & Durbin-Watson \\
\hline 1 & .901 & .959 & .867 & .24413 & .867 & 304.074 & 3 & 39 & .000 & 1.841 \\
\hline
\end{tabular}
ficient $b$ or Factor III is very small.

Table 9 shows the parameter values of the predicted model results and the $t$ values by analyzing them for each variable at the $5 \%$ significance level.

Table 8. Summary of the model of implications or insufficient savings due to financial behavior

Source: Authors' own computations. 
Lulaj, E., Dragusha, B., Lulaj, D., Rustaj, V., Gashi, A. (2021). Households savings and financial behavior in relation to the ability to handle financial emergencies: case study of Kosovo. Acta Sci. Pol. Oeconomia 20 (1), 35-47, DOI: 10.22630/ASPE.2021.20.1.4

Table 9. Coefficients for Factor III - implications or non-savings due to financial behavior

\begin{tabular}{|c|c|c|c|c|c|}
\hline \multicolumn{6}{|l|}{ Coefficient } \\
\hline & & \multicolumn{4}{|l|}{ Model } \\
\hline & & constant & INVLL & MVKRRSH & HTFM \\
\hline \multirow[t]{2}{*}{ Unstandardized coefficients } & $B$ & .211 & .376 & .341 & .542 \\
\hline & $S D$ & .285 & .084 & .099 & .175 \\
\hline Standardized coefficients & beta & & -.247 & -.187 & 1.263 \\
\hline$t$ & & -.2672 & 4.012 & .1646 & 5.361 \\
\hline Sig. & & .000 & .000 & .000 & .000 \\
\hline \multirow[t]{2}{*}{$95.0 \%$ confidence interval for $B$} & lower bound & -.1343 & -.424 & -.376 & 1.286 \\
\hline & upper bound & -.182 & -.083 & .028 & 1.998 \\
\hline \multirow[t]{2}{*}{ Collinearity statistics } & tolerance & & .439 & .359 & .467 \\
\hline & VIF & & .939 & .850 & .861 \\
\hline
\end{tabular}

Dependent variable: implications or non-saving due to financial behavior

Source: Authors' own computation.s

The constant in the value of .211 indicates that if the implications or non-savings based on the independent variables: INVLL, MVKRRSH, HTFM is zero, then Factor III has an accuracy of $21 \%$. If the implications or non-savings due to financial behavior are made in accordance with the independent variables the accuracy will be $=126 \%($ INVLL $=38 \%$, MVKRRSH $=$ $34 \%$, HTFM $=54 \%$ ). The beta coefficient indicates that all independent variables are important in the model, the most important variable being HTFM. Collinearity statistics including tolerance and VIF values $(.439=.939, .359=.850, .467=.861)$ are important in the model because there is no problem of multiple relationships between independent variables.

$$
\begin{aligned}
\hat{y} & =\alpha_{0}+\beta_{1}(\mathrm{INVLL})+\beta_{2}(\mathrm{MVKRRSH})+\beta_{3}(\mathrm{HTFM})= \\
& =0.211+0.376 x_{1}+0.341 x_{2}+0.542 x_{3}+0.04 \mu \\
F & =\frac{R^{2} / k}{\left(1-R^{2}\right) /(n-k-1)}=\frac{.959 / 3}{(1-.959) / 39}=\frac{0.319667}{0.041 / 39}= \\
& =\frac{0.319667}{0.00105128}=304.074081
\end{aligned}
$$

Reliability interval 95\% (Sig. 2-tailed), $p=0.000$ $<0.05, t=4.012, .1646,5.361>.6423$, the value of $\mathrm{p}$ is less than the significance level $5 \%, \mathrm{H}_{0}$ is rejected and accepted $\left(\beta_{1}, \beta_{2}, \beta_{3}\right) \neq 0$

\section{CONCLUSION}

Factor analysis of financial behavior of households in relation to savings: a reflection of the financial situation for emergencies. Based on the questionnaire which was distributed and completed by households, 3 factors were created from 13 variables, therefore in the model of factor analysis and reliability analysis all results are acceptable and have very high reliability (i.e. in each factor created by the variables we have results as: $\mathrm{KMO}>.0500$, Barlett test (Sig.) $=.000$, Variance $>.500$, Alpha $>.700$, Eigen value $>50 \%$. In this case it has been shown that saving factors and financial behavior are important (have a positive effect) on families for emergencies. For each factor, the variance fits the factor where it further specifies the econometric model of financial behavior in relation to savings. 
Lulaj, E., Dragusha, B., Lulaj, D., Rustaj, V., Gashi, A. (2021). Households savings and financial behavior in relation to the ability to handle financial emergencies: case study of Kosovo. Acta Sci. Pol. Oeconomia 20 (1), 35-47, DOI: 10.22630/ASPE.2021.20.1.4

Multiple regression analysis: Multiple regression analysis: To make the model more relevant and robust, all factors from the results of factor analysis and reliability were further processed through multiple regression analysis for savings and financial behavior variables. In this case the factors from 1-3 emphasize that they are important in the regression model for households (i.e. $R^{2}>50 \%$, correlation analysis $<.0800$, Anova $(p)=.000<0.05$, Durbin-Watson test to all factors it is within the mean and there is no autocorrelation, all independent variables affect (are important to) the model or the dependent variable. But care must be taken to improve the emergency sub-factor.

\section{Rationale for proving the $\boldsymbol{H}_{A}$ hypothesis}

$\mathrm{H}_{\mathrm{A}}$ : Savings factors and financial behavior are important (have a positive effect) on households for emergencies. Starting from literature review, financial behavior practices in relation to savings, research data methodology according to the method of factor analysis, reliability analysis, multiple regression analysis, and extensive research results in the interpretation of the main results and findings, proves that the alternative hypothesis has a positive effect on households. In some variables, where the tests were positive but with a lower value, households should take into account the recommendations of the research in order to further increase financial behavior in relation to savings, especially for emergencies.

\section{REFERENCES}

Aguiar, M., Amador, M. (2011). Growth in the Shadow of Expropriation. The Quarterly Journal of Economics, 126 (2), 651-697, https://doi.org/10.1093/qje/qjr015

Bacha, E.L. (1990). A three-gap model of foreign transfers and the GDP growth rate in developing countries. Journal of Development economics 32 (2), 279-296.

Bai, A., Hira, S., Deshpande, P.S. (2015). An Application of Factor Analysis in the Evaluation of Country Economic Rank. Procedia Computer Science, 54, 311-317, https:// doi.org/10.1016/j.procs.2015.06.036

Bajtelsmit, V., Bernasek, A., Jianakoplos, A. (1999). Gender differences in defined contribution pension. Financial Services Review, 8 (1), 1-10, https://doi.org/10.1016/ S1057-0810(99)00030-X
Baker, H.K., Filbeck, H., Ricciardi, V. (2017). Financial Behavior: Players, Services, Products, and Markets (Financial Markets and Investments). Oxford University Press, Oxford.

Beck, T., Levine, R., Loayza, N. (2000). Finance and the sources of growth. Journal of Financial Economics, 58 (1-2), 261-300, https://doi.org/10.1016/S0304$405 \mathrm{X}(00) 00072-6$

Beck, T., Demirguc-Kunt, A., Levine, R. (2007). Finance, inequality and the poor. Journal of Economic Growth, 12, 27-49, https://doi.org/10.1007/s10887-007-9010-6

Bernheim, D., Garrett, M. (1996.) The determinants and consequences of financial education in the workplace. NBER Working Paper, 5667, 1-54, https://doi. org/10.3386/w5667

Bremer, M. (2012). Multiple linear regression-Math 261A. Reliawiki. Retrieved from http://reliawiki.org/index. php/Multiple_Linear_Regression_Analysis [accessed 20.11.2020].

Callen, T., Thiman, Ch. (1997). Empirical Determinants of Household Saving: Evidence from OECD Countries. International Monetary Fund, Washington.

Campbell, Th. (1996). Investigating structures underlying relationships when variables are not the focus: Technique and other techniques. Advances in Social Science Methodology, 4, 207-218.

Castellani, G., DeVaney, A.Sh. (2001). Using credit to cover living expenses: a profile of a potentially risky behavior. Family Economics and Nutrition Review, 13 (2), 12.

Chowdhury, A. (2004). Private Savings in Transition Economies: Are There Terms of Trade Shocks? Comparative Economic Studies, 46 (4), 1-35, https://doi.org/ 10.1057/ palgrave.ces. 8100027

Chowdhury, A. (2015). Terms of Trade Shocks and Private Savings in the Developing Countries. Journal of Comparative Economics, 43 (4), 1122-1134.

Collins, J. M., Gjertson, L. (2013). Emergency Savings for Low-Income Consumers. Focus, 30 (1), 12-17.

Cronbach, L., Gleser, G. (1959). Interpretation of reliability and validity coefficients: Remarks on a paper by Lord. Journal of Educational Psychology, 50 (5), 230-237, https://doi.org/10.1037/h0042848

Deaton, A. (1992). Understanding Consumption. Clarendon Press, Oxford.

Dupas, P., Robinson, J. (2013). Savings Constraints and Microenterprise Development: Evidence from a Field Experiment in Kenya. American Economic Journal: Applied Economics, 5 (1), 163-192, http://dx.doi. org/10.1257/app.5.1.163 
Lulaj, E., Dragusha, B., Lulaj, D., Rustaj, V., Gashi, A. (2021). Households savings and financial behavior in relation to the ability to handle financial emergencies: case study of Kosovo. Acta Sci. Pol. Oeconomia 20 (1), 35-47, DOI: 10.22630/ASPE.2021.20.1.4

Fehr, D., Hishigsuren, G. (2006). Raising capital for microfinance: sources of funding and opportunities for equity financing. Journal of Developmental Entrepreneurship, 11 (2), 133-143, https://doi.org/10.1142/ S1084946706000301

Feldt, L. (1969). A test of the hypothesis that Cronbach's alpha or Kuder Richardson coefficient twenty is the same for two tests. Psychometrika, 34, 363-373 (1969). https://doi.org/10.1007/BF02289364

Ferraro, F., Su, P. (1999). Financial strain, social relations, and psychological distress among older people: A crosscultural analysis. The Journals of Gerontology Series B: Psychological Sciences and Social Science, 54B (1), 3-15, https://doi.org/10.1093/geronb/54b.1.s3

Fry, T., Mihajilo, S., Russell, R., Brooks, R. (2008). The factors influencing saving in a matched savings program: Goals, knowledge of payment instruments, and other behavior. Journal of Family and Economic, 29, 234-250.

Furnham,A. (1999). The saving and spending habits of young people. Journal of Economic Psychology, 20 (6), 677697, https://doi.org/10.1016/S0167-4870(99)00030-6

Gokhale, J., Kotlikoff, L. (1999). The Impact of Social Security and Other Factors on the Distribution of Wealth. London School of Economics - Centre for Labor Economics. Retrieved from https://econpapers.repec.org/ paper/fipfedcwp/9913.htm [accessed 20.11.2020].

Gómez, F. (2009). Educación financiera: retos y lecciones a partir de experiencias representativas en el mundo. Proyecto Capital enbreve, 10, 1-7. Retrieved from https://repositorio.iep.org.pe/bitstream/IEP/1054/1/ G\%c3\%b3mez-Franz Educacion-financiera-retos-lecciones.pdf [accessed 22.11.2020].

Gustman, L.A., Steinmeier, Th.L. (2000). Retirement in Dual-Career Families: A Structural Model. Journal of Labor Economics, 18 (3), 503-545, https://doi. org/10.1086/209968.

Hebbel, Sh.H., Webb, S.B., Corsetti, G. (1992). Household Saving in Developing Countries: First Cross-Country Evidence. World Bank Economic Review, 6 (3), 529-547 .

Henson, R., Roberts, J.K. (2006). Use of Exploratory Factor Analysis in Published Research Common Errors and Some Comment on Improved Practice. Educational and Psychological Measurement, 66 (3), 393-416, https:// doi.org/10.1177/0013164405282485

Hilgert, M.A., Hogarth, J.M., Beverly, S. (2003). Household financial management: The connection between knowledge and behavior. Federal Reserve Bulletin, July, 309-322, https://doi.org/10.1.1.379.9686
Hogarth, J. M., Anguelov, C. (2003). Can the poor save? Journal of Financial Counseling and Planning 14 (1), 1-18.

Jacobs-Lawson, J.M., Hershey, D. (2005). Influence of future time perspective, financial knowledge, and financial risk tolerance on retirement saving behaviors. Financial Services Review, 14, 331. Retrieved from https://www. semanticscholar.org/paper/Influence-of-future-timeperspective\%2C-financial-and-Jacobs-Lawson-Hershey/d3e1409d17d7149780c90573e71ea15cac16abcc [accessed 19.11.2020].

Jamieson, T., Jamieson, P. (2009). Ministry and Money: A Practical Guide for Pastors. John Knock Press, Kentucky, Louisiana.

Karlan, D., Morduch, J. (2009). Access to Finance. [In:] D. Rodrick, M.R. Rosenzweig (Eds), Handbook of development economics, vol. 5. North Holland, 1-86. Retrieved from http://citeseerx.ist.psu.edu/viewdoc/do wnload?doi=10.1.1.205.6947\&rep=rep1\&type $=$ pdf [accessed 20.11.2020].

Kieffer, K.M., Kevin, M. (1999). An introductory primer on the appropriate use of exploratory and confirmatory factor. Research in the Schools, 6 (2), 75-92.

King, G., Levine, R. (1993). Finance and growth: Schumpeter might be right. Quarterly Journal of Economics, 108 (3), 1-50, https://doi.org/10.2307/2118406

Klapper L., Laeven L., Rajan R. (2006). Entry Regulation as a Barrier to Entrepreneurship. Journal of Financial Economics, 82 (3), 591-269, https://doi.org/10.1016/ j.jfineco.2005.09.006

Kleinman, G., Anandarajan A., Lawrence K. (1999). An analysis of the move toward defined contribution pension plans: are the rewards commensurate with the risks? Journal of Pension Planning and Compliance, 25, 61-89.

Kotlikoff, J., Morris, N. (1989). How much care do the aged receive from their children? A bimodal picture of contact assistance. [In:] D.A. Wise (Ed.) The Economics of Aging. University of Chicago Press, Chicago, IL.

Lulaj, E. (2020). Budget education and management a necessity for Well-being and financial stability: Cluster \& MDS analysis. International Journal of Financial Research 11 (6), 348-364.

Lusardi, A., Mitchelli, O.S. (2007). Financial Literacy and Retirement Preparedness: Evidence and Implications for Financial Education. Business Economics, 42 (1), 35-44, https://doi.org/10.2145/20070104

Mandell, L., Klein K.L. (2009). The Impact of Financial Literacy Education on Subsequent Financial Behavior. Journal of Financial Counseling and Planning, 20 (1), 15-24. 
Lulaj, E., Dragusha, B., Lulaj, D., Rustaj, V., Gashi, A. (2021). Households savings and financial behavior in relation to the ability to handle financial emergencies: case study of Kosovo. Acta Sci. Pol. Oeconomia 20 (1), 35-47, DOI: 10.22630/ASPE.2021.20.1.4

Meier, S., Sprenger, C. (2008). Discounting financial literacy: Time preferences and participation in financial education programmers. Journal of Economic Behavior and Organization, 95, 159-174.

Misztal, P. (2011). The Relationship between Savings and Economic Growth in Countries with Different Level of Economic Development. Finansowy Kwartalnik Internetowy e-Fínanse, 7 (2), 17-29.

Morin, J.H., Ralyté, J., Snene, M. (2010). Exploring Services Science. [In:] First International Conference, IESS 2010. Springer, February 17-19, Geneva, Switzerland, https://doi.org/10.1007/978-3-030-38724-2_24

Nageeb, A. (2011). Learning Self-Control. The Quarterly Journal of Economics, 126 (2), 857-893, https://doi. org/10.1093/qje/qjr014

Niculescu, A.I., Mihaescu, M. (2014). Modelling the Impact of Economic, Demographic and Social Determinants on Household Saving Rate in the Former Socialist Countries (Central and Eastern Europe). Procedia Economics and Finance, 10, 104-113, https://doi.org/ 10.1016/ S2212-5671(14)00283-4

Robb, A.C., Woodyard, A. (2011). Financial Knowledge and Best Practice Behavior. Journal of Financial Counseling and Planning, 22(1), 36-46.

Rooij, M., Lusardi, A., Alessie, R. (2011). Financial Literacy, Retirement Planning and Household Wealth. NBER Working Paper, 313, 1-54.

Scholtz, J. (1992). A direct examination on the dividend clientele hypothesis. Journal of Public Economics, 49 (3), 261-285, https://doi.org/10.1016/00472727(92)90069-R

Schreiner, M., Sherraden, M. (2007). Can the Poor Save? Saving and Asset Building in Individual Development Accounts. Transaction Publishers, New Brunswick, NJ.
Sherraden, M. (1991). Assets and the Poor: A New American Welfare Policy. Center for Social Development Research, M.E. Sharpe, Inc., New York.

Shin, S.H., Kim, K.T. (2018). Perceived income changes, saving motives, and household savings. Journal of Financial Counseling and Planning, 29 (2), 396-409.

Sonuga, J., Webley P. (1993). Children's saving: A study in the development of economic behavior. Journal of Economic Psychology, 15 (2), 375-378.

Stephen, M.A. (1988). Relational concepts in psychoanalysis: An integration. Harvard University Press, Cambridge.

Sterns, L. (1998). The decision to retire or work. [In:] K.W. Schaie, C. Schooler (Eds), Impact of work on older adults. Springer, New York.

Tampis, R.L., Urrutia, J.D. (2017). Regression analysis of the economic factors of the gross domestic product in the Philippines. Journal of Fundamental and Applied Sciences, 9 (7S), 190-291.

Thompson, B., Daniel, L.G. (1996). Factor analytic evidence for the construct validity of scores: A historical overview and some guidelines. Educational and Psychological Measurement, 56 (2), 197-208. Retrieved from https://aquila.usm.edu/fac_pubs/5558 [accessed 22.11.2020].

Wiatrowski, W. (1993). Factors affecting retirement income. Monthly Labor Review, 16 (3), 25-35. Retrieved from https://www.researchgate.net/publication/287936634 Factors_affecting_retirement_income [accessed 22.11.2020].

Zhuk, M. (2015). Macroeconomic Determinants of Household Savings in Ukraine. Economics and Sociology, 8 (3), 41-54, https://doi.org/10.14254/2071789X.2015/8-3/3

Zsuzsannaa, T., Liviu, M. (2012). Multiple regression analysis of performance indicators in the ceramic industry. Procedia Economics and Finance, 3, 509-514.

\section{OSZCZĘDNOŚCI GOSPODARSTW DOMOWYCH I ZACHOWANIA FINANSOWE W ZWIAZZKU Z UMIEJĘTNOŚCIĄ PORADZENIA SOBIE Z TRUDNYMI SYTUACJAMI FINANSOWYMI: STUDIUM PRZYPADKU KOSOWA}

\section{STRESZCZENIE}

Chcąc odzwierciedlić sytuację finansową gospodarstw domowych, zwłaszcza w sytuacjach kryzysowych, przyjęto główny cel niniejszego badania - analizę zachowań finansowych w odniesieniu do oszczędności. Niniejsze badanie wyjaśnia interakcję zasad minimalnych oszczędności i zaangażowanych form oszczędzania, co oznacza, że wykorzystanie budżetów osobistych zależy od zachowań finansowych wynikających z niepewności i sytuacji finansowej rodzin. Badanie jest zgodne z niektórymi empirycznymi ustaleniami 
Lulaj, E., Dragusha, B., Lulaj, D., Rustaj, V., Gashi, A. (2021). Households savings and financial behavior in relation to the ability to handle financial emergencies: case study of Kosovo. Acta Sci. Pol. Oeconomia 20 (1), 35-47, DOI: 10.22630/ASPE.2021.20.1.4

dotyczącymi zachowań finansowych w odniesieniu do oszczędności, które wpływają na wzrost lub upadek gospodarki, ponieważ im niższy dobrobyt rodzin, tym niższy wzrost gospodarczy lub odwrotnie. Weryfikacja hipotez została zrealizowana poprzez analizę ustaleń terenowych z wykorzystaniem ekonometrycznego modelu oszczędności w odniesieniu do zachowań finansowych poprzez analizę czynnikową, analizę rzetelności oraz analizę regresji wielorakiej. Głównym wnioskiem z tego badania jest brak zachowań finansowych w celu oszczędzania na sytuacje awaryjne. Ustalenia te są ważne, by uświadomić gospodarstwom domowym roli oszczędzania na pokrycie awaryjnych potrzeb.

Słowa kluczowe: oszczędności, zachowania finansowe, analiza regresji wielorakiej, gospodarstwa domowe, ekonomia wzrostu i spadku 